\title{
PENGARUH TRANSFER MODAL MANUSIA ANTARGENERASI TERHADAP MOBILITAS PENDAPATAN ANTARGENERASI DI INDONESIA
}

\author{
Ari Purbowati \\ Program Pascasarjana Ilmu Ekonomi Universitas Indonesia \\ E-mail: purbowati.ari@gmail.com
}

\begin{abstract}
ABSTRAK. Penelitian ini bertujuan untuk mengukur mobilitas pendapatan antargenerasi dan melihat pengaruh transfer modal manusia antargenerasi terhadap mobilitas pendapatan antargenerasi di Indonesia. Data yang digunakan adalah pasangan bapak dan anak yang bersumber dari IFLS periode 2000 sampai 2014. Dengan menggunakan metode 2SLS diketahui bahwa modal manusia secara langsung diturunkan dari orang tua kepada anaknya. Elastisitas pendapatan antargenerasi (IGE) meningkat dari 0.118 menjadi 0.151 ketika transfer langsung modal manusia diperhitungkan. Dengan kata lain transfer langsung modal manusia memperkuat IGE Hal ini memberikan indikasi bahwa ketika pengembangan modal manusia anak diserahkan sepenuhnya kepada keputusan rumah tangga, maka kesenjangan pendapatan yang terjadi pada generasi orang tua akan cenderung diwariskan atau dipertahankan kepada generasi anak.
\end{abstract}

Kata kunci: mobilitas pendapatan antargenerasi, elastisitas pendapatan antargenerasi, IGE, modal manusia, pendidikan, transfer langsung, Klasifikasi JEL: I24, I25, J24

\section{EFFECT OF INTERGENERATIONAL TRANSFER OF HUMAN CAPITAL ON INTERGENERATIONAL INCOME MOBILITY IN INDONESIA}

\begin{abstract}
The purpose of this study are to estimate the intergenerational income mobility and the effect of intergenerational transfer of human capital on intergenerational income mobility in Indonesia. The intergenerational income elasticity is estimated by using father-child pairs from Indonesia Family Life Survey (IFLS) 2000 until IFLS 2014. This study apply 2SLS method and the estimation resuts suggests that human capital is directly transmitted from parent to child. IGE increased from 0.118 to 0.151 when the direct transfer of human capital are taken into account. In other words, the direct transfer of human capital strengthening IGE. This is an indication that when the human capital development of children left entirely to household decisions, then the income gap that occurs in the older generation tends to be inherited or maintained for generations of children.
\end{abstract}

Key words: intergenerational income mobility, intergenerational income elasticity, IGE, human capital, direct transfer, education JEL Codes : I24, I25, J24

\section{PENDAHULUAN}

Mobilitas pendapatan antargenerasi, yang biasanya diukur dengan IGE (Intergenerational Income Elasticity), merupakan salah satu kunci untuk mengetahui kesenjangan ekonomi. Mobilitas pendapatan antargenerasi yang tinggi menunjukkan bahwa pendapatan anak tidak terlalu terkait dengan pendapatan orang tua (Mayer \& Lopoo, 2008). Hal tersebut dapat terjadi dalam masyarakat ketika peluang anak untuk mendapatkan pendapatan tidak sepenuhnya ditentukan oleh orang tua tetapi juga oleh faktor lain yang ada di masyarakat, misalnya kesempatan belajar atau kesempatan untuk berusaha (Black \& Devereux, 2010). Sebaliknya, jika mobilitas pendapatan antargenerasi rendah menunjukkan bahwa pendapatan yang diperoleh anak dimasa yang akan datang sangat terkait dengan pendapatan orang tua.

Studi empiris mengenai mobilitas pendapatan antar generasi masih sangat terbatas di negara berkembang. Salah satu penyebabnya adalah kurangnya sumber data yang memadai untuk melakukan estimasi mobilitas pendapatan antargenerasi (Qin, Wang, \&
Zhuang, 2016). Hal serupa juga disampaikan oleh Hertz \& Jayasundera (2007) dalam penelitiannya mengenai mobilitas pendidikan antargenerasi di Indonesia yaitu pada dasarnya sangat sulit untuk mengestimasi mobilitas pendapatan antargenerasi dengan menggunakan data yang tersedia di negara berkembang karena mayoritas negara berkembang tidak memiliki data panel yang cukup panjang untuk mengestimasi pendapatan permanen.

Disisi lain, mobilitas pendapatan antargenerasi merupakan isu yang telah lama menjadi perhatian masyarakat, khususnya pemangku kebijakan dan kalangan akademik. Bagi pemangku kebijakan, isu ini penting untuk melihat sejauh mana keterkaitan antara pendapatan orang tua dengan pendapatan anak (Solon, 1992) dan apa saja saluran yang mempengaruhi keterkaitan tersebut, misalnya Qin, Wang, \& Zhuang (2016) mengamati saluran modal manusia yaitu melalui pendidikan dan kesehatan serta melihat pengaruhnya terhadap mobilitas pendapatan di China, Bevis \& Barrett (2015) mengamati saluran modal manusia (pendidikan dan kesehatan) dan modal fisik (lahan pertanian) dalam mengukur mobilitas pendapatan antargenerasi di rural Filipina, Björklund, Roine, \& Waldenström (2012) 
mengamati saluran pendidikan, IQ, dan kemampuan non-kognitif dalam mengukur mobilitas pendapatan antargenerasi di Swedia. Adanya keterkaitan yang kuat antara pendapatan orang tua dengan pendapatan anak memberi indikasi bahwa kesenjangan yang terjadi pada generasi orang tua cenderung dipertahankan atau diwariskan pada generasi selanjutnya (Björklund \& Jäntti, 2009). Sebagai contoh, orang tua yang kaya akan berinvestasi lebih banyak dalam modal manusia anakanaknya daripada orang tua yang miskin, sehingga di masa yang akan datang pendapatan anak dari orang tua yang kaya relatif lebih tinggi dibandingkan pendapatan anak dari orang tua yang miskin (Bevis \& Barrett, 2015). Tain (2013) dalam tulisannya juga menyebutkan bahwa di Wilayah Tangkap Lebih Jawa Timur, rumah tangga nelayan banyak yang miskin karena tingkat pendidikan yang rendah. Pendidikan rendah ini bertahan dari generasi ke generasi sehingga tidak membuat kondisi ekonomi membaik dari generasi ke generasi. Selain itu, mobilitas pendapatan antargenerasi memberi gambaran mengenai sejauh mana masyarakat mampu memberikan kesempatan yang sama kepada setiap orang, contohnya anak-anak dari keluarga berpendapatan rendah mempunyai kesempatan untuk sukses sebagaimana anakanak dari keluarga kaya atau seseorang memperoleh pekerjaan berdasarkan keahliannya bukan berdasarkan latar belakang keluarga (Mayer \& Lopoo, 2008; Black \& Devereux, 2010).

Sementara itu, bagi kalangan akademik, isu yang penting dalam mobilitas pendapatan antargenerasi adalah mendapatkan ukuran mobilitas pendapatan antargenerasi yang baik. Pengukuran mobilitas pendapatan antar generasi memiliki beberapa masalah empiris. Pertama, ukuran mobilitas pendapatan antargenerasi akan tepat jika pengukuran pendapatan permanen dilakukan dengan baik (Black \& Devereux, 2010). Kedua, ukuran mobilitas pendapatan antargenerasi akan mengandung bias jika tidak memperhitungkan "direct transfer" atau transfer langsung modal manusia antargenerasi (Qin, Wang, \& Zhuang, 2016).

Terkait dengan isu transfer modal manusia antar generasi, mobilitas pendapatan antargenerasi tergantung seberapa baik generasi muda dalam mengembangkan modal manusianya. Ada indikasi bahwa ketika transfer langsung modal manusia dari orang tua kepada anak tidak diperhitungkan maka ukuran mobilitas pedapatan antargenerasi akan mengandung bias, yaitu IGE yang dihasilkan akan cenderung bias ke bawah. Bukti empiris di China mengatakan bahwa transfer langsung modal manusia memperkuat besaran IGE. Melalui penelitiannya, Qin, Wang dan Zhuang (2016) menunjukkan bahwa IGE di China meningkat dari 0.429 menjadi 0.481 ketika transfer langsung modal manusia (melalui pendidikan dan kesehatan) dari orang tua ke anak dipertimbangkan. Ukuran mobilitas pendapatan di China menjadi terlalu tinggi ketika transfer langsung modal manusia antargenerasi tidak dipertimbangkan
Berdasarkan uraian di atas, penelitian ini akan mengisi kekurangan informasi mengenai mobilitas pendapatan antargenerasi di Indonesia. Dapat dikatakan bahwa penelitian ini merupakan penelitian awal mengenai mobilitas pendapatan antargenerasi di Indonesia. Sejauh ini penelitian mengenai mobilitas pendapatan antargenerasi belum pernah dilakukan di Indonesia karena masalah keterbatasan data sehingga informasi mengenai mobilitas pendapatan antar generasi di Indonesia belum ada informasinya. Hertz \& Jayasundera (2007) dalam penelitiannya mengenai mobilitas pendidikan antargenerasi di Indonesia berpendapat bahwa pada dasarnya sangat sulit untuk mengestimasi persistensi pendapatan antargenerasi dengan menggunakan data yang tersedia di negara berkembang. Hal ini dikarenakan mayoritas negara berkembang tidak memiliki data panel yang cukup panjang untuk mengestimasi pendapatan permanen.

Secara khusus, penelitian ini akan menyajikan pengukuran pendapatan permanen orang tua dengan menggunakan data IFLS tahun 2000, 2007, dan 2014. Pengukuran pendapatan permanen orang tua akan menggunakan rata-rata pendapatan orang tua dari tahun 2000, 2007, dan 2014. Rata-rata pendapatan dari tiga sampai lima titik pengamatan merupakan ukuran yang akurat untuk pendapatan permanen (Solon, 1992; Zimmerman, 1992). Melalui penelitian empirisnya, Solon (1992) menganalisis mengenai mobilitas pendapatan antargenerasi di US dengan menggunakan data dari tahun 1967-1971 dan menemukan bahwa estimasi IGE di US dengan menggunakan rata-rata pendapatan orang tua dari 3 titik pengamatan menghasilkan estimasi yang mirip ketika menggunakan rata-rata pendapatan orang tua dari empat atau lima titik pengamatan, yaitu sekitar 0.4, di mana angka tersebut lebih besar dari penelitian sebelumnya yaitu sekitar 0.2 .

Selain itu, penelitian ini juga akan melihat pengaruh dari transfer modal manusia antargenerasi terhadap mobilitas pendapatan antargenerasi di Indonesia. Untuk melihat hubungan ini, penelitian ini akan memodifikasi model teoritis dan model empiris dari literatur sebelumnya (Qin, Wang, \& Zhuang, 2016). Pada model teoritis, penelitian ini menggunakan kerangka OLG untuk melihat pengaruh transfer modal manusia terhadap IGE. Pada analisis empiris, penelitian ini akan menggunakan data pasangan bapak dan anak dari IFLS3 (tahun 2000), IFLS4 (tahun 2007) dan IFLS5 (tahun 2014) yang bekerja dengan penghasilan untuk melihat transfer modal manusia antargenerasi dan pengaruhnya terhadap IGE dengan menggunakan metode estimasi 2SLS. Saluran atau transmisi modal manusia pada penelitian ini masih terbatas pada saluran pendidikan, sementara dalam literatur yang ada terdapat saluran transmisi modal manusia yang lain seperti kesehatan (Bevis \& Barrett, 2015; Qin, Wang, \& Zhuang, 2016), IQ, dan kemampuan non-kognitif (Björklund, Roine, \& Waldenström, 2012) 
Mobilitas pendapatan antargenerasi umumnya diukur dengan menghitung korelasi pendapatan antar generasi, atau yang lebih dikenal dengan sebutan IGE. IGE diestimasi melalui regresi linier dari logaritma pendapatan permanen anak terhadap logaritma pendapatan permanen orang tua (Solon, 1992; Black \& Devereux; 2010; Blanden et.al., 2014; Piraino, 2015; Yuan, 2015; Qin, Wang \& Zhuang, 2016). Koefisien dari logaritma pendapatan permanen orang tua inilah yang disebut sebagai IGE. IGE menunjukkan derajat persistensi pendapatan antargenerasi (Blanden et al., 2014; Piraino, 2015).

Metode dalam mengestimasi IGE mengalami perkembangan dari waktu ke waktu. Perkembangan metode ini semakin menarik karena mulai muncul banyak perdebatan tentang pengukuran pendapatan permanen orang tua. Pengukuran pendapatan permanen orang tua yang tidak tepat dapat menyebabkan bias pada IGE (Solon, 1992; Behrman \& Taubman, 1990; Solon, 2002; Black \& Devereux, 2010; Bevis \& Barrett, 2015). Pertama, bias yang disebabkan oleh kesalahan pengukuran pada pendapatan permanen orang tua (Solon, 1992; Solon, 2002; Yuan, 2015; Bevis \& Barrett, 2015). Hal tersebut terjadi ketika pendapatan pada waktu tertentu (single year income) digunakan sebagai pendekatan untuk mengukur pendapatan permanen orang tua. Pendapatan pada tahun tertentu bukan pendekatan yang tepat untuk mengukur pendapatan permanen orang tua karena masih mengandung unsur pendapatan permanen dan fluktuasi sementara (Solon, 1992; Solon, 2002; Mazumder, 2005). Bias yang terjadi karena kesalahan pengukuran dapat dikoreksi dengan menggunakan rata-rata pendapatan orang tua di beberapa tahun pengamatan. Penggunaan rata-rata pendapatan umumnya dapat meningkatkan IGE di US dan UK (Solon, 1992; Blanden J. , 2013) yaitu sekitar 0.4 dan di Kanada dan negara bagian di Eropa (Corak \& Heisz, 1999; Osterbacka, 2001; Solon, 2002) yaitu sekitar 0.1-0.2. Kedua, bias yang disebabkan oleh efek umur dan life cycle. Bias yang terjadi karena efek life cycle dapat diatasi dengan memasukkan kuadrat umur anak sebagai variabel kontrol dalam model (Solon, 1992; Black \& Devereux, 2010; Bevis \& Barrett, 2015).

Meskipun pendapatan permanen orang tua yang telah diproksi dengan menggunakan rata-rata pendapatan dapat mengatasi bias, tetapi hasilnya masih mengandung variasi yang bersifat sementara. Bevis \& Barret (2015) mengatakan bahwa variasi yang bersifat sementara pada pendapatan permanen disebabkan adanya efek dari pendapatan sementara (transitory income) dan guncangan harga (price shock), sehingga estimasi IGE yang dihasilkan masih terlalu rendah (underestimate) pada kebanyakan penelitian yang ada. Menurut mereka bias yang disebabkan oleh guncangan sementara dapat dikurangi dengan menggunakan panel data yang panjang. Hal ini dikarenakan guncangan sementara mempunyai kecenderungan untuk bertahan atau terjadi sepanjang waktu. Pernyataan serupa juga disampaikan oleh Mazumder (2005) ketika menggunakan data dari US social security, estimasi IGE meningkat menjadi 0.61 ketika menggunakan rata-rata pendapatan selama 16 tahun dari sebelumnya yaitu 0.45 ketika menggunakan rata-rata pendapatan selama 7 tahun.

Sementara itu, terdapat perdebatan pula dalam pengukuran pendapatan permanen anak juga. Beberapa penelitian menggunakan pendapatan anak pada tahun tertentu sebagai pendekatan dalam mengukur pendapatan permanen anak. Pendapatan permanen anak yang diukur dengan pendapatan pada tahun tertentu tidak akan menyebabkan bias pada estimasi karena merupakan variabel dependen (Zimmerman, 1992; Gong, Leigh, \& Meng, 2012; Yuan, 2015; Qin, Wang, \& Zhuang, 2016). Kesalahan pengukuran pada pendapatan permanen anak akan menjadi satu dengan eror pada persamaan regresi (Zimmerman, 1992). Pendapatan tahun tertentu sebenarnya kurang tepat dalam menggambarkan pendapatan permanen anak ketika pendapatan tersebut diambil pada usia muda (misal di bawah 30 tahun). Haider \& Solon (2006) dan Böhlmark \& Lindquist (2006) berpendapat bahwa pendapatan pendapatan tahun tertentu masih merupakan ukuran yang baik untuk pendapatan permanen jika pendapatan tersebut diukur pada umur antara 30 sampai 40 tahun. Umur 30-40 tahun merupakan usia prima dimana pada saat itu seseorang mempunyai pendapatan yang stabil sehingga lebih dapat menggambarkan pendapatan permanen anak. Akan tetapi karena observasi yang digunakan akan lebih sedikit ketika menggunakan umur anak antara 30-40 tahun, maka beberapa penelitian tetap menggunakan semua observasi tetapi dengan menambahkan kuadrat umur anak pada persamaan regresi untuk mengatasi dampak life cycle.

Terkait dengan isu mengenai transfer modal manusia antargenerasi, modal manusia antargenerasi mempunyai peranan penting dalam mobilitas pendapatan antar generasi. Penelitian-penelitian mengenai mobilitas pendapatan antar generasi (Solon, 2002; Mayer \& Loppo, 2007; Nakamura \& Murayama, 2011; Blanden et al, 2014) hanya terfokus pada transfer modal manusia antar generasi melalui saluran investasi modal manusia yang dibuat oleh orang tua untuk anak dan belum mempertimbangkan transfer langsung modal manusia dari orang tua kepada anak. Idenya adalah orang tua akan menggunakan modal manusianya untuk memperoleh pendapatan. Pendapatan tersebut akan dialokasikan salah satunya untuk investasi terhadap modal manusia anakanaknya. Modal manusia anak akan mempengaruhi pendapatan anak di masa yang akan datang. Orang tua yang berpendidikan tinggi akan mempunyai penghasilan yang tinggi dan sumber daya atau tenaga yang lebih untuk berinvestasi pada pendidikan anakanaknya sehingga di masa yang akan datang anak-anak mempunyai pendidikan yang tinggi sehingga memiliki penghasilan yang tinggi juga. Qin, Wang, \& Zhuang 
(2016) menyebut mekanisme ini sebagai transfer tidak langsung modal manusia dari orang tua kepada anak. Dalam penelitiannya Qin, Wang, \& Zhuang (2016) menjelaskan bahwa “... ketika pendapatan seseorang ditentukan oleh akumulasi modal manusianya, modal manusia orang tua akan mempengaruhi kemampuan finansialnya untuk berinvestasi pada modal manusia anaknya dan akan mempengaruhi pendapatan anak di masa yang akan datang”. Dengan kata lain modal manusia orang tua ditularkan secara tidak langsung kepada modal manusia anak melalui saluran investasi modal manusia.

Akan tetapi, modal manusia tidak hanya ditularkan secara tidak langsung dari orang tua kepada anak tetapi juga ditularkan secara langsung. Qin, Wang, \& Zhuang (2016) menyebut mekanisme ini sebagai transfer langsung atau "direct transfer" modal manusia antargenerasi, sebagaimana ditulis “... modal manusia orang tua dapat secara langsung ditularkan kepada anakanaknya melalui saluran genetik atau non-genetik yang juga akan mempengaruhi pendapatan anak di masa yang akan datang". Dapat dikatakan bahwa orang tua akan secara langsung menularkan modal manusianya kepada anak melalui saluran genetik (misalnya IQ atau kemampuan kognitif) dan saluran non-genetik seperti kebiasaan (misalnya anak-anak belajar dari orang tua melalui aktivitas sehari-hari) dan cara didik (Bevis \& Barrett, 2015; Qin, Wang, \& Zhuang, 2016). Pada gambar 1 dijelaskan dengan singkat mengenai transfer modal manusia dari orang tua kepada anak baik secara tidak langsung maupun secara langsung. Dalam teorinya mengenai mobilitas antargenerasi, Becker et al. (2015) menggambarkan bahwa pendidikan membantu orang tua untuk memilih input yang lebih efektif dalam meraih capaian anak. Orang tua yang berpendidikan mempunyai pengetahuan yang lebih baik dalam sistem pendidikan yang dapat membantu proses pendidikan anak-anaknya dan lebih produktif dalam mengajar anak-anak mereka. Bevis \& Barrett (2015) menyatakan bahwa pendidikan orang tua dapat mempengaruhi preferensi orang tua dan keputusan untuk berinvestasi ke modal manusia anakanaknya. Sebagai contoh, orang tua yang berpendidikan rendah tidak akan percaya bahwa pendidikan merupakan faktor yang penting dalam menentukan pendapatan anak di masa yang akan datang sehingga mereka cenderung menyekolahkan anaknya pada level pendidikan yang tidak terlalu tinggi dan lebih menginginkan anak-anaknya untuk memperoleh pekerjaan lebih awal. Selain itu, Herrington (2015) mengatakan bahwa salah satu faktor yang mempengaruhi kemampuan belajar individu adalah pendidikan orang tua, di mana kemampuan tersebut menggambarkan efisiensi individu dalam memproduksi modal manusianya yang nantinya akan menentukan pendapatannya di pasar kerja. Dalam penelitiannya, Hertz et al. (2007) juga menemukan bahwa korelasi pendidikan antara orang tua dan anak di Indonesia masih cenderung tinggi yaitu sekitar 0.55 . Hal ini menandakan bahwa pendidikan orang tua masih sangat berperan dalam menentukan pendidikan anak.

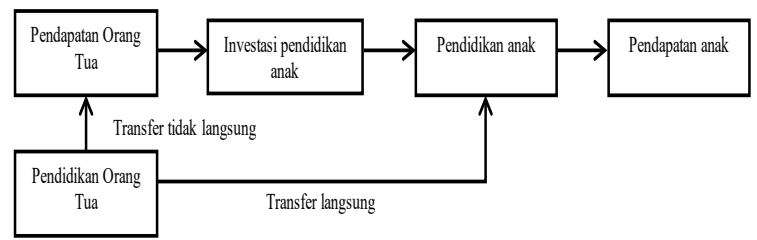

Gambar 1. Mekanisme transfer langsung dan tidak langsung modal manusia antar generasi dan hubungannya dengan mobilitas pendapatan antargenerasi

Pengaruh transfer langsung maupun transfer tidak langsung modal manusia antargenerasi terhadap mobilitas pendapatan antargenerasi dapat dijelaskan melalui model OLG (overlapping-generations). Qin, Wang, \& Zhuang (2016) menjelaskan secara konseptual pengaruh transfer modal manusia antargenerasi terhadap mobilitas pendapatan menggunakan model OLG untuk menunjukkan bahwa ketika transfer langsung modal manusia antargenerasi tidak diperhitungkan dalam pengukuran mobilitas pendapatan antargenerasi, maka IGE yang dihasilkan akan cenderung bias ke bawah. Mereka menggunakan pendekatan yang dibangun oleh Becker \& Tomes (1979) yang mengasumsikan bahwa orang tua bersifat altruistik dan memaksimumkan kepuasan atas konsumsi mereka dan ekspektasi pendapatan anak dimasa yang akan datang dengan kendala pendapatan orang tua sekarang.

Dalam model OLG, diasumikan individu melalui tiga tahap kehidupan, yaitu anak-anak, individu muda yang bekerja, dan individu tua (pensiun). Pada tahap pertama, individu mengakumulasikan modal manusia pada saat anak-anak, sehingga dibayangkan anak-anak tidak melakukan keputusan, tetapi orang tua yang nantinya menentukan berapa modal manusia anaknya. Pada tahap kedua, individu muda menggunakan akumulasi modal manusia semasa kecil untuk mendapatkan pekerjaan dan memperoleh pendapatan, sehingga pendapatan seseorang $\left(y_{t}^{p}\right)$ ditentukan oleh akumulasi modal manusianya $\left(h_{t}^{p}\right)$, yaitu:

$y_{t}^{p}=\left(h_{t}^{p}\right)^{\gamma}$

$\gamma \gamma$ merupakan kontribusi relatif dari modal manusia terhadap pendapatan. Nilai $\gamma$ adalah antara 0 dan 1 ( $0<\gamma<1$ ). Pengembalian marginal dari modal manusia terhadap pendapatan atau dapat juga diinterpretasikan sebagai produktivitas diasumsikan sebagai diminishing marginal return (Qin, Wang, \& Zhuang, 2016). Akan tetapi, karena dalam penelitian ini modal manusia akan diukur melalui pendidikan, tidak menutup kemungkinan bahwa pengembalian marginal dari modal manusia terhadap pendapatan diasumsikan sebagai increasing marginal return dengan nilai $\gamma$ lebih dari 1. Salah satu alasannya adalah pendidikan merupakan hal yang nondefeasible, sehingga kenaikan satu tahun pendidikan 
di tingkat yang lebih tinggi akan lebih meningkatkan pendapatan. Seperti dikutip oleh Senoaji (2011), menurut teori Human Capital, salah satu hal yang menentukan kualitas sumber daya manusia adalah tingkat pendidikan. Pendidikan dipandang dapat meningkatkan produktivitas (pendapatan). Nilai $\gamma$ tidak mungkin di bawah 0, karena akan mengakibatkan nilai elastisitas pendapatan orang tua terhadap pendapatan anak atau nilai IGE menjadi negatif.

Pada saat yang bersamaan, individu muda yang bekerja harus membuat keputusan berapa banyak pendapatan $\left(y_{t}^{p}\right)$ yang digunakan untuk konsumsi $\left(k_{t}^{p}\right)$, ditabung untuk hari tua $\left(s_{t}^{p}\right)$ dan diinvestasikan kepada anak-anak mereka $\left(e_{t}^{p}\right)$.

$y_{t}^{p}=k_{t}^{p}+s_{t}^{p}+e_{t}^{p}$

Jika individu muda lebih banyak menggunakan pendapatannya untuk konsumsi, maka pendapatan yang ditabung dan diinvestasikan akan lebih sedikit, sehingga generasi yang akan datang tidak lebih sejahtera. Sebaliknya, jika individu muda semakin banyak menggunakan pendapatannya untuk investasi, maka generasi yang akan datang akan lebih sejahtera meskipun konsumsi orang tua di masa yang akan datang lebih sedikit.

Pada tahap ketiga, individu tua akan pensiun dan menghabiskan tabungannya $\left(1+R_{t}\right) s_{t}^{p}$ untuk konsumsi $k_{t+1}^{p}$.

$k_{t+1}^{p}=\left(1+R_{t}\right) s_{t}^{p}$

$R_{t}$ adalah tingkat bunga (interest rate) pada periode $t$.

Pada generasi anak, pendapatan anak pada periode

$t+1$ juga ditentukan oleh akumulasi modal manusia pada saat $t+1$, sehingga :

$y_{t+1}^{c}=\left(h_{t+1}^{c}\right)^{\gamma}$

Akumulasi modal manusia dari individu tergantung pada kemampuan bawaan $\left(A_{\mathrm{t}}^{c}\right)$ dan investasi modal manusia dari orang tuanya $\left(e_{t}^{p}\right)$ sehingga :

$h_{\mathrm{t}+1}^{c}=A_{\mathrm{t}}^{c}\left(e_{\mathrm{t}}^{p}\right)^{1-\sigma}$

$(1-\sigma)$ merupakan kontribusi relatif dari investasi modal manusia terhadap stok modal manusia. Pengembalian marginal dari investasi modal manusia diasumsikan sebagai diminishing marginal return. Menurut Becker et.al (2015) "Terdapat diminishing return dari $y$ (investasi orang tua terhadap anak) sehingga menjadi sangat sulit untuk menambah pengetahuan kepada anak dengan kapasitas mental tertentu" (Becker et.al, 2015, p.4-5). Dapat dikatakan bahwa, modal manusia mempunyai batas optimal. Ketika modal manusia mencapai batas yang optimal, maka penambahan investasi modal manusia tidak akan menyebabkan kenaikan modal manusia.

Diasumsikan bahwa kemampuan bawaan dari individu ditentukan secara random, maka :

$\ln A_{t}^{c}=\ln \bar{A}+\varepsilon_{t}$

$\ln \bar{A}$ menunjukkan nilai rata-rata dari $\ln A_{t}^{c}$ dan $\varepsilon_{t}$ adalah random shock yang mengikuti distribusi normal. Ketika orang tua tidak mengetahui kemampuan bawaan anak, maka orang tua akan membentuk ekspektasi terhadap kemampuan bawaan anak berdasarkan kemampuan bawaan orang tua.

Berdasarkan tiga tahap kehidupan, yaitu anakanak, individu muda yang bekerja, dan individu tua (pensiun), individu hanya membuat keputusan pada tahap kedua kehidupannya, sehingga kepuasan yang diharapkan dari individu muda yang bekerja tergantung pada konsumsi saat $t$, ekspektasi konsumsi saat $t+1$ dan ekspektasi pendapatan anak saat $t+1$. $E U_{t}^{p}=u\left(k_{t}^{p}\right)+\beta E_{t} u\left(k_{t+1}^{p}\right)+\beta \alpha E_{t} u\left(y_{t+1}^{c}\right) \ldots .(7)$

Fungsi kepuasan dituliskan dalam bentuk logaritma (Solon, 2004; Qin, Wang, dan Zhuang, 2016) dan masalah optimisasi menjadi :

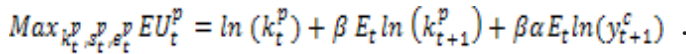

s.t. $k_{t}^{p}+s_{t}^{p}+e_{t}^{p}=y_{t}^{p}$

$k_{t+1}^{p}=\left(1+R_{t}\right) s_{t}^{p}$

Berdasarkan persamaan (5), (4), (3), dan (8) diperoleh persamaan Lagrange yaitu:

$\varepsilon=\ln \left(k_{t}^{p}\right)+\beta \ln \left(1+R_{t}\right)+\beta \ln \left(s_{t}^{p}\right)+\alpha \beta \gamma \ln A^{p}+a \beta \gamma(1-\sigma) \ln e_{t}^{p}+\lambda_{1}\left[y_{t}^{p}-k_{t}^{p}-s_{t}^{p}-\theta_{t}^{p}\right]+\lambda_{2}\left[\left(1+R_{t}\right) s_{t}^{p}-\right.$ $\left.k_{t+1}^{p}\right]$

Turunan pertama (first order conditions) dari persamaan (9) terhadap konsumsi pada saat $t\left(k_{t}^{p}\right)$, terhadap tabungan pada saat $t\left(s_{t}^{p}\right)$, dan terhadap investasi modal manusia pada saat $t\left(e_{t}^{p}\right)$, yaitu :

$\frac{1}{k_{\mathrm{t}}^{D}}=\frac{\alpha \beta \gamma(1-\sigma)}{e_{\mathrm{t}}^{D}}$

$\frac{1}{k_{t}^{D}}=\frac{\beta\left(1+R_{t}\right)}{k_{t+1}^{D}}$

Berdasarkan persamaan (3), (2), (10), dan (11), diperoleh investasi modal manusia dari orang tua ke anak, $e_{*}^{p}$, vang optimal, yaitu :

$e_{t}^{p}=y_{t}^{p} \frac{\alpha \beta \gamma(1-\sigma)}{1+\beta+\alpha \beta \gamma(1-\sigma)}$

Fungsi transmisi pendapatan antargenerasi diperoleh dengan menyubtitusi persamaan (5), (6), dan (12) ke persamaan (4) dan dituliskan dalam bentuk logaritma vaitu:

$\ln y_{t+1}^{c}=\gamma \ln \bar{A}+\gamma(1-\sigma) \ln \frac{\alpha \beta \gamma(1-\sigma)}{1+\beta+\alpha \beta \gamma(1-\sigma)}+\gamma(1-\sigma) \ln y_{t}^{p}+\gamma \varepsilon_{t} \ldots$.

Berdasarkan persamaan (13), elastisitas pendapatan antargenerasi (IGE) adalah sebesar $\gamma(1-\sigma)$. Hal ini menunjukkan bahwa IGE ditentukan oleh pengembalian marginal dari modal manusia terhadap pendapatan dan pengembalian marginal investasi modal manusia.

Oleh karena salah satu tujuan penelitian adalah melihat pengaruh transfer langsung modal manusia orang tua kepada anak dan pengaruhnya terhadap mobilitas pendapatan, maka untuk menangkap mekanisme transfer langsung modal manusia dari orang tua kepada anak, penelitian ini memodifikasi model transmisi langsung dari Qin, Wang, \& Zhuang (2016). Modal manusia tidak hanya berasal dari investasi modal manusia dari orang tua ke anak tetapi juga diturunkan dari modal manusia orang tua ke anak, sehingga fungsi akumulasi modal manusia dapat dimodifikasi dengan penambahan $h_{t}^{p}$ ke persamaan (5) menjadi : 
$h_{t+1}^{c}=A_{t}^{c}\left(h_{t}^{p}\right)^{\sigma}\left(e_{t}^{p}\right)^{1-\sigma}, 0<\sigma<10<\sigma<1(14)$

$\left(h_{t}^{p}\right)^{\sigma}$ menggambarkan transfer langsung modal manusia dari orang tua kepada anaknya dan bersamasama dengan $e_{t}^{p}$ menentukan $h_{t+1}^{c}$ melalui fungsi Cobb-Douglas.

Solusi optimal untuk $e_{t}^{p}$ tidak berubah ketika persamaan (5) diganti dengan persamaan (14) pada masalah optimisasi, tetapi fungsi transmisi pendapatan antargenerasi akan berubah. Fungsi transmisi pendapatan antargenerasi diperoleh dengan menyubtitusi persamaan (1), (6), (12), dan (14) ke persamaan (4) dan dituliskan dalam bentuk logaritma, vaitu :

$\ln y_{t+1}^{c}=\gamma \ln \bar{A}+\gamma(1-\sigma) \ln \frac{a \beta \gamma(1-\sigma)}{1+\beta+\alpha \beta \gamma(1-\sigma)}+\gamma \sigma \ln h_{t}^{p}+\gamma(1-\sigma) \ln y_{t}^{p}+\gamma \varepsilon_{t}$.

Ketika $\ln h_{t}^{p}=\frac{1}{\gamma} \ln y_{t}^{p}$, yang merupakan inverse function dari $y_{t}^{p} \stackrel{\gamma}{=}\left(h_{t}^{p}\right)^{\gamma}$, disubtitusikan ke persamaan (15), maka fungsi transmisi pendapatan antargenerasi meniadi :

$\ln y_{t+1}^{c}=\gamma \ln \bar{A}+\gamma(1-\sigma) \ln \frac{\alpha \beta \gamma(1-\sigma)}{1+\beta+\alpha \beta \gamma(1-\sigma)}+[\sigma+\gamma(1-\sigma)] \ln y_{t}^{p}+\gamma \varepsilon_{t} \ldots$.

Persamaan (16) menghasilkan IGE sebesar $\sigma+\gamma(1-\sigma)$. IGE tidak hanya dipengaruhi oleh pengembalian marginal dari modal manusia terhadap pendapatan dan pengembalian marginal investasi modal manusia, tetapi juga pengembalian marginal dari modal manusia orang tua terhadap modal manusia anak. Jika dibandingkan dengan IGE pada persamaan (13), maka IGE pada persamaan (16) lebih besar daripada IGE pada persamaan (13). Berdasarkan hal tersebut dapat ditarik dugaan bahwa transfer langsung modal manusia dari orang tua kepada anak mempengaruhi besaran IGE. IGE yang memperhitungkan transfer langsung modal manusia dari orang tua kepada anak akan lebih besar daripada IGE yang tanpa meperhitungkan transfer modal manusia dari orang tua kepada anak.

Sumber data yang akan digunakan pada penelitian ini adalah IFLS3, IFLS4, dan IFLS5 dengan unit analisis pasangan orang tua dan anak yang bekerja dan mendapat penghasilan. Informasi mengenai pendapatan orang tua akan diambil dari IFLS3, IFLS4, dan IFLS5, informasi mengenai pendidikan orang tua akan diambil dari IFLS, sedangkan informasi mengenai pendapatan anak dan karakteristik anak akan diambil dari IFLS5. Dalam penelitan ini dibatasi bahwa orang tua adalah bapak kandung dari anak (Björklund, Roine, \& Waldenström, 2012). Jika satu bapak kandung memiliki lebih dari satu anak yang bekerja dengan penghasilan pada tahun 2014, maka semua observasi anak dipakai dalam penelitian ini untuk mendapatkan ukuran sampel yang lebih besar (Mazumder, 2005; Björklund, Roine, \& Waldenström, 2012; Yuan, 2015).

Jumlah pasangan bapak-anak yang teridentifikasi adalah 4,777 pasang bapak-anak yang terdiri dari 837 pasang bapak-anak di mana bapak hanya mempunyai informasi pendapatan di satu titik waktu saja, 1,149 pasang bapak-anak di mana bapak mempunyai informasi pendapatan di 2 titik, dan 2,791 pasang bapak-anak di mana bapak mempunyai informasi pendapatan di 3 titik waktu. Dalam penelitian ini akan menggunakan pasangan bapak-anak di mana bapak memiliki pendapatan di 3 titik yang untuk selanjutnya disebut sampel 1 dan pasangan bapak-anak di mana bapak memiliki pendapatan minimal 2 titik waktu (gabungan 2 titik waktu dan 3 titik waktu) yang untuk selanjutnya disebut sampel 2. Jumlah observasi sampel 1 adalah 2,791 pasang dan jumlah observasi sampel 2 adalah 3,940 pasang.

\section{METODE}

Tujuan penelitian ini adalah mendapatkan ukuran mobilitas pendapatan antargenerasi yang baik melalui IGE. Dalam mengestimasi IGE, penelitian ini akan memperhatikan mekanisme transfer langsung modal manusia dari orang tua kepada anak. Ada dugaan bahwa transfer langsung modal manusia antargenerasi dapat mempengaruhi besaran IGE. Oleh karena itu, dalam penelitian ini menggunakan dua model persamaan yaitu model persamaan tunggal dan model persamaan simultan.

Model persamaan tunggal merupakan model persamaan yang biasa digunakan untuk mengestimasi IGE. Model ini akan diestimasi menggunakan metode OLS (Ordinary Least Squares). Spesifikasi modelnya

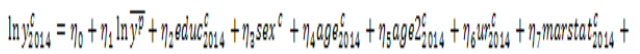

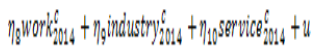

Model persamaan simultan digunakan untuk menangkap pengaruh transfer modal manusia antargenerasi terhadap mobilitas pendapatan antargenerasi sesuai dengan kerangka konseptual yang telah disajikan. Model ini akan diestimasi menggunakan metode 2SLS (Two-Stage Least Square). Spesifikasi modelnya adalah:

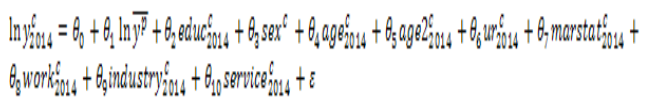

${ }_{e d u} d u c_{2014}^{c}=a_{0}+a_{1} e d u c_{2000}^{p}+a_{2} \ln y^{\bar{p}}+a_{2} \operatorname{sex} c+a_{4} a g g_{2014}^{c}+a_{5} u u_{2014}^{c}+v$. dimana :

$\begin{array}{ll}y_{2014}^{c} & \begin{array}{l}\text { pendapatan permanen anak yang diukur } \\ \text { dengan pendapatan tahun } 2014\end{array} \\ \overline{y^{p}} & \begin{array}{l}\text { pendapatan permanen orang tua yang } \\ \text { diukur dengan rata-rata pendapatan dari } \\ \text { tahun 2000, 2007, dan 2914 }\end{array} \\ e d u c_{2000}^{p} & =\text { lama pendidikan bapak pada tahun } 2000 \\ e d u c_{2014}^{c} & =\text { lama pendidikan anak pada tahun } 2014 \\ \operatorname{sex}^{c} & =\text { jenis kelamin anak } \\ a g e_{2014}^{c} & =\text { umur anak pada tahun 2014 } \\ a g e 2_{2014}^{c} & =\text { kuadrat umur anak pada tahun } 2014\end{array}$




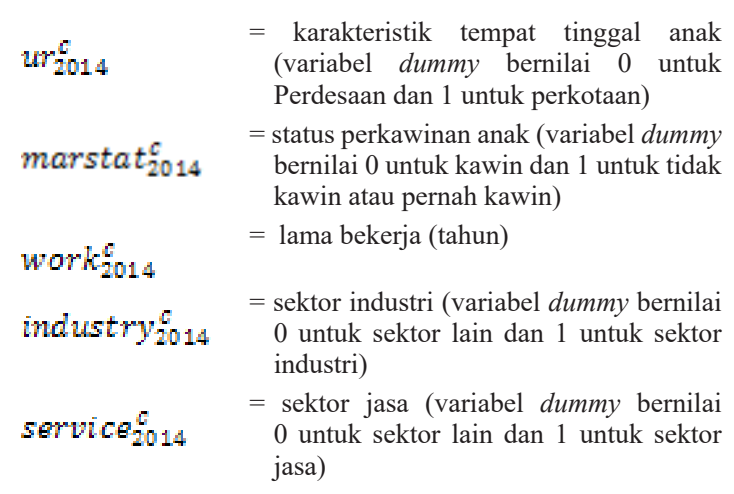

Pendapatan bapak dan anak pada penelitian ini diambil dari pendapatan yang diperoleh dari bekerja (labor income) baik dari pekerjaan utama maupun pekerjaan tambahan. Pendapatan ini akan diukur dengan menggunakan pendapatan tahunan. Pendapatan tahunan diperolehdari informasi pendapatan selama 12 bulan yang lalu. Jika informasi tidak tersedia, maka pendapatan tahunan dihitung dengan menggunakan pendapatan selama sebulan yang lalu dikali 12. Pendapatan tahunan bapak dari tahun 2000, 2007, dan 2014 akan dikonversikan ke dalam tahun dasar 1996 untuk menghilangkan pengaruh kenaikan harga. Begitu pula dengan pendapatan tahunan anak 2014 akan dikonversi ke tahun 1996. Informasi mengenai pendapatan diperoleh dari buku 3A sesi TK. Pendapatan permanen bapak akan dihitung dengan menggunakan ratarata pendapatan tahunan, sedangkan pendapatan permanen anak akan dihitung dengan menggunakan pendapatan tahun 2014.

Lama pendidikan bapak dan anak digunakan sebagai ukuran dari modal manusia. Lama pendidikan dihitung dari tingkat pendidikan tertinggi dan kelas yang pernah diduduki. Informasi mengenai tingkat pendidikan dan kelas yang pernah diduduki diperoleh dari buku kontrol AR (ar16 dan ar17) dan buku 3A sesi DL (dl04, d106, dan d107). Lama pendidikan bapak diukur pada tahun 2000, sedangkan lama pendidikan anak diukur pada tahun 2014.

Umur dan kuadrat umur anak digunakan sebagai variabel kontrol untuk mengatasi efek life cycle (Solon, 1992; Mazumder, 2005; Bevis \& Barrett, 2015). Umur anak diobservasi pada tahun 2014. Dampak kuadrat umur anak terhadap pendapatannya diharapkan mempunyai pola atau bentuk $U$ terbalik yang menggambarkan diminishing marginal return dari umur. Informasi mengenai umur diperoleh dari buku kontrol AR (ar09).

Jenis kelamin anak digunakan sebagai variabel kontrol dalam model persamaan pendapatan anak untuk menangkap perbedaan pendapatan yang diperoleh oleh laki-laki maupun perempuan. Sementara pada persamaan pendidikan anak, jenis kelamin digunakan untuk menangkap ekspektasi yang berbeda dari orang tua terhadap hasil pendidikan anak laki-laki maupun perempuan. Jenis kelamin anak akan disajikan dalam bentuk variabel dummy, di mana 0 adalah perempuan dan 1 adalah laki-laki. Informasi mengenai jenis kelamin terdapat pada buku kontrol AR (ar07).

Status perkawinan ditandai dengan ada tidaknya ikatan perkawinan. Status perkawinan dalam penelitian ini merupakan variabel dummy yang bernilai 0 jika berstatus kawin dan bernilai 1 jika tidak kawin atau pernah kawin. Status perkawinan dapat memberikan pengaruh yang berbeda kepada pendapatan. Individu yang berstatus kawin mempunyai kecenderungan mendapatkan pendapatan yang lebih tinggi terkait dengan tunjangan yang diterima. Informasi mengenai status perkawinan diperoleh dari buku kontrol sesi AR (ar13).

Lapangan pekerjaan adalah bidang pekerjaan dari pekerjaan atau tempat bekerja di mana seseorang bekerja. Lapangan pekerjaan dalam penelitian ini dikelompokkan menjadi tiga kelompok. Pertama adalah lapangan pekerjaan sektor pertanian, yang terdiri dari pertanian, kehutanan, perikanan, dan perburuan. Kedua adalah lapangan pekerjaan sektor industri, yang terdiri dari pertambangan dan penggalian; manufaktur; listrik, gas, air bersih; bangunan; dan industri. Ketiga adalah lapangan pekerjaan sektor jasa yang terdiri dari perdagangan besar, eceran, rumah makan, dan hotel; angkutan; pergudangan dan komunikasi; keuangan; asuransi; usaha persewaan bangunan, real estate, dan jasa perusahaan; serta kemasyarakatan. Kategori yang dijadikan kelompok referensi adalah individu yang bekerja di sektor pertanian. Terdapat dua variabel dummy yaitu industri, yang bernilai 1 jika lapangan pekerjaan utamanya adalah di sektor industri dan 0 lainnya, serta variabel jasa yang bernilai 1 jika lapangan pekerjaan utamanya adalah jasa dan 0 jika lainnya. Informasi mengenai lapangan pekerjaan diperoleh dari buku 3A modul TK.

Karakteristik wilayah tempat tinggal anak digunakan sebagai variabel kontrol dalam persamaan pendapatan anak dan persamaan pendidikan anak. Karakteristik tempat tinggal akan disajikan dalam bentuk variabel dummy, di mana 0 adalah rural (perdesaan) dan 1 adalah urban (perkotaan). Akses untuk mendapatkan fasilitas sekolah lebih baik di perkotaan dan hal ini dapat mendorong pendidikan anak menjadi lebih baik. Selain itu, karakteristik wilayah juga mempengaruhi pendapatan yang diperoleh. Informasi mengenai karakteristik wilayah diperoleh dari buku kontrol sesi SC (SC05).

\section{HASIL DAN PEMBAHASAN}

Secara statistik, pendapatan permanen orang tua, pendapatan permanen anak, pendidikan orang tua dan beberapa variabel lain dalam pengukuran mobilitas pendapatan antargenerasi dapat dilihat pada tabel 1 . dan tabel 2. Tabel 1. menyajikan statistik deskriptif dari observasi sampel 1. Sampel 1 adalah pasangan bapak dan anak di mana bapak mempunyai informasi pendapatan lengkap di 3 titik waktu. Tabel 2 menyajikan statistik deskriptif dari observasi sampel 2. Sampel 2 adalah 
Tabel 1. Statistik Deskriptif Pasangan Bapak dan Anak dari Sampel 1

\begin{tabular}{|c|c|c|c|c|c|}
\hline \multirow{2}{*}{ Variabel } & \multirow{2}{*}{$\begin{array}{c}\text { Total } \\
\text { Mean }\end{array}$} & \multirow{2}{*}{$\frac{\text { Anak Laki-laki }}{\text { Mean }}$} & \multirow{2}{*}{$\begin{array}{c}\text { Anak } \\
\text { Perempuan } \\
\text { Mean }\end{array}$} & \multirow{2}{*}{$\frac{\text { Perdesaan }}{\text { Mean }}$} & \multirow{2}{*}{$\frac{\text { Perkotaan }}{\text { Mean }}$} \\
\hline & & & & & \\
\hline \multicolumn{6}{|l|}{ Variabel anak } \\
\hline Pendapatan tahunan (Ribu Rupiah) & 5,944 & 6,626 & 4,802 & 4,742 & 6,633 \\
\hline Lama pendidikan (tahun) & 10.77 & 10.51 & 11.20 & 9.81 & 11.31 \\
\hline Umur anak (tahun) & 26.38 & 26.60 & 26.01 & 26.66 & 26.22 \\
\hline $\begin{array}{l}\text { Status perkawinan }(0 . \text { kawin, } 1 . t i d a k / \text { pernah } \\
\text { kawin) }\end{array}$ & 0.47 & 0.50 & 0.42 & 0.38 & 0.52 \\
\hline Lama bekerja (bulan) & 46.26 & 49.75 & 40.41 & 52.82 & 42.50 \\
\hline Sektor industri (1. industri, 0.lainnya) & 0.31 & 0.30 & 0.31 & 0.33 & 0.29 \\
\hline Sektor jasa (1. Jasa, 0. Lainnya) & 0.49 & 0.47 & 0.51 & 0.38 & 0.55 \\
\hline \multicolumn{6}{|l|}{ Variabel bapak } \\
\hline Pendapatan tahunan (Ribu Rupiah) & 10,700 & 10,000 & 11,800 & 8,831 & 11,800 \\
\hline Lama pendidikan (tahun) & 6.39 & 6.28 & 6.57 & 5.11 & 7.12 \\
\hline Observasi & 2,791 & 1,747 & 1,044 & 1,017 & 1,774 \\
\hline
\end{tabular}

Sumber : IFLS3, IFLS4, dan IFLS5, diolah Sampel 1 adalah pasangan bapak dan anak di mana bapak mempunyai informasi pendapatan lengkap di 3 titik waktu

Sampel 2 juga mempunyai pola yang sama dengan sampel 1 dalam hal pendapatan anak dan pendapatan bapak. Pendapatan tahunan anak lebih rendah daripada rata-rata pendapatan bapak. Rata-rata umur anak pada sampel 2 adalah 27 tahun. Rata-rata lama pendidikan bapak dan anak tidak jauh berbeda dengan sampel 1.

pasangan bapak dan anak di mana bapak mempunyai informasi pendapatan minimal 2 titik waktu.

Jumlah pasangan bapak dan anak pada sampel 1 adalah 2,791 pasang dengan 1,747 pasang bapak - anak laki-laki dan 1,044 pasang bapak - anak perempuan, sedangkan jumlah pasangan bapak dan anak pada sampel 2 adalah 3,940 pasang dengan 2,470 pasang bapak - anak laki-laki dan 1,470 pasang bapak - anak perempuan.

Pendapatan tahunan anak pada sampel 1 lebih rendah daripada rata-rata pendapatan tahunan bapak. Hal ini dikarenakan pengukuran pendapatan anak dilakukan pada saat umur anak belum optimal sebagaimana dilihat bahwa rata-rata umur anak pada tahun 2014 adalah 26 tahun. Pendapatan anak kemungkinan masih akan mengalami kenaikan. Berdasarkan total sampel 1, anak yang berstatus tidak/pernah kawin adalah sebesar $47 \%$. Rata-rata lama bekerja anak adalah sebesar 46 bulan.

Rata-rata lama pendidikan bapak adalah sekitar 6.4 tahun, sedangkan rata-rata lama pendidikan anak sekitar 10.77 tahun. Hal ini menandakan bahwa mayoritas bapak hanya menamatkan pendidikannya sampai tamat sekolah dasar. Adanya peningkatan lama pendidikan menandakan bahwa modal manusia meningkat pada generasi anak. Peningkatan modal manusia ini akan berakibat peningkatan pendapatan anak pada masa yang akan datang.

Rata-rata lama pendidikan anak laki-laki lebih rendah daripada anak perempuan pada kedua sampel. Demikian juga untuk rata-rata lama pendidikan di daerah perkotaan lebih tinggi daripada rata-rata lama pendidikan di daerah perdesaan pada kedua sampel data.
Tabel 3. dan tabel 4. menunjukkan hasil regresi dengan metode OLS. Masing-masing tabel menggunakan sampel pasangan yang berbeda dalam mengestimasi IGE. Tabel 3. menggunakan sampel 1, sedangkan tabel 4. menggunakan sampel 2. Model (1) merupakan model persamaan tunggal yang diestimasi menggunakan OLS, sedangkan model(2) dan(3) merupakan model persamaan simultan yang diestimasi dengan menggunakan 2SLS. Model (2) merujuk pada model empiris pada persamaan (17) yaitu model persamaan regresi konvensional yang digunakan untuk memperoleh IGE yaitu dengan menyertakan variabel kontrol karakteristik anak dan karakteristik pekerjaan anak. Model (2) dan model (3) merupakan model persamaan simultan yang digunakan untuk menangkap pengaruh transfer langsung modal manusia dari bapak ke anak yang mengacu pada (19) dan mengukur IGE persamaan (18).

Berdasarkan tabel 3. estimasi IGE pada model (1) dengan mengontrol karakteristik anak dan karakteristik pekerjaan anak menghasilkan angka sebesar 0.118, artinya jika rata-rata pendapatan tahunan bapak meningkat sebesar 1 persen maka rata-rata pendapatan anak akan meningkat sebesar 0.118 persen. Pada model (1) terlihat bahwa lama pendidikan anak berpengaruh signifikan terhadap pendapatan anak dengan koefisien sebesar 0.086, yang artinya ketika lama pendidikan meningkat sebesar 1 tahun, maka pendapatan akan meninggkat sebesar 8.6 persen ketika hal lainnya dikontrol. Dampak umur anak terhadap pendapatannya mempunyai bentuk U terbalik. Hal ini menggambarkan diminishing marginal return dari umur. 
Tabel 2.Statistik Deskriptif Pasangan Bapak dan Anak dari Sampel 2

\begin{tabular}{|c|c|c|c|c|c|}
\hline \multirow[t]{2}{*}{ Variabel } & Total & Anak Laki-laki & $\begin{array}{c}\text { Anak } \\
\text { Perempuan } \\
\end{array}$ & Perdesaan & Perkotaan \\
\hline & Mean & Mean & Mean & Mean & Mean \\
\hline \multicolumn{6}{|l|}{ Variabel anak } \\
\hline Pendapatan tahunan (Ribu Rupiah) & 6,295 & 6,924 & 5,238 & 5,006 & 7,010 \\
\hline Lama pendidikan (tahun) & 10.76 & 10.42 & 11.32 & 9.78 & 11.30 \\
\hline Umur anak (tahun) & 27.13 & 27.29 & 26.86 & 27.32 & 27.02 \\
\hline Status perkawinan (0. kawin, 1.tidak/pernah kawin) & 0.45 & 0.47 & 0.41 & 0.37 & 0.49 \\
\hline Lama bekerja (bulan) & 49.35 & 51.81 & 45.23 & 55.78 & 45.79 \\
\hline Sektor industri (1. industri, 0.lainnya) & 0.30 & 0.30 & 0.30 & 0.31 & 0.30 \\
\hline Sektor jasa (1. Jasa, 0. Lainnya) & 0.49 & 0.47 & 0.51 & 0.39 & 0.54 \\
\hline \multicolumn{6}{|l|}{ Variabel bapak } \\
\hline Pendapatan tahunan (Ribu Rupiah) & 16,900 & 9,309 & 29,600 & 26,300 & 11,600 \\
\hline Lama pendidikan (tahun) & 6.41 & 6.21 & 6.76 & 5.17 & 7.10 \\
\hline Observasi & 3,940 & 2,470 & 1,470 & 1,405 & 2,535 \\
\hline
\end{tabular}

Sumber : IFLS3, IFLS4, dan IFLS5, diolah Sampel 2 adalah pasangan bapak dan anak di mana bapak mempunyai informasi pendapatan minimal 2 titik waktu.

Tabel 3. Hasil Estimasi IGE dengan Menggunakan Sampel Pasangan 1

\begin{tabular}{|c|c|c|c|c|c|c|}
\hline \multirow{3}{*}{ Variabel } & \multirow{2}{*}{\multicolumn{2}{|c|}{$\begin{array}{c}\text { OLS } \\
\begin{array}{c}\text { Log natural pendapatan tahunan } \\
\text { anak }\end{array}\end{array}$}} & \multicolumn{4}{|c|}{ Persamaan Simultan } \\
\hline & & & \multirow{2}{*}{\multicolumn{2}{|c|}{$\begin{array}{c}\begin{array}{c}\text { Log natural pendapatan tahunan } \\
\text { anak }\end{array} \\
(2)\end{array}$}} & \multicolumn{2}{|c|}{ Lama Pendidikan anak } \\
\hline & \multicolumn{2}{|c|}{$(1)$} & & & \multicolumn{2}{|c|}{ (3) } \\
\hline \multirow{2}{*}{$\begin{array}{l}\text { Log natural rata-rata pendapatan } \\
\text { tahunan bapak }\end{array}$} & 0.118 & $* * *$ & 0.151 & $* * *$ & 0.561 & $* * *$ \\
\hline & $(0.026)$ & & $(0.034)$ & & $(0.063)$ & \\
\hline \multirow[t]{2}{*}{ Lama pendidikan anak } & 0.086 & $* * *$ & 0.055 & $* *$ & & \\
\hline & $(0.008)$ & & $(0.022)$ & & & \\
\hline \multirow{2}{*}{ Lama pendidikan bapak } & & & & & 0.322 & $* * *$ \\
\hline & & & & & $(0.016)$ & \\
\hline \multirow{2}{*}{ Jenis Kelamin anak } & -0.449 & $* * *$ & -0.430 & $* * *$ & 0.553 & $* * *$ \\
\hline & $(0.053)$ & & $(0.054)$ & & $(0.119)$ & \\
\hline \multirow{2}{*}{ Umur anak } & 0.343 & $* * *$ & 0.369 & $* * *$ & 0.019 & ** \\
\hline & $(0.030)$ & & $(0.035)$ & & $(0.009)$ & \\
\hline \multirow{2}{*}{ Kuadrat umur anak } & -0.005 & $* * *$ & -0.006 & $* * *$ & & \\
\hline & $(0.001)$ & & $(0.001)$ & & & \\
\hline \multirow{2}{*}{ Urban/rural } & 0.204 & $* * *$ & 0.233 & $* * *$ & 0.669 & $* * *$ \\
\hline & $(0.055)$ & & $(0.058)$ & & $(0.123)$ & \\
\hline \multirow{2}{*}{ Status perkawinan } & 0.113 & * & 0.150 & $* *$ & & \\
\hline & $(0.064)$ & & $(0.069)$ & & & \\
\hline \multirow{2}{*}{ Lama bekerja } & 0.006 & $* * *$ & 0.006 & $* * *$ & & \\
\hline & $(0.001)$ & & $(0.001)$ & & & \\
\hline \multirow{2}{*}{ Sektor_industri } & 0.452 & $* * *$ & 0.450 & $* * *$ & & \\
\hline & $(0.072)$ & & $(0.072)$ & & & \\
\hline \multirow{2}{*}{ Sektor_jasa } & 0.443 & $* * *$ & 0.452 & $* * *$ & & \\
\hline & $(0.067)$ & & $(0.068)$ & & & \\
\hline \multirow{2}{*}{ Konstanta } & 6.281 & $* * *$ & 5.689 & $* * *$ & -1.170 & \\
\hline & $(0.590)$ & & $(0.709)$ & & $(1.005)$ & \\
\hline observasi & 2,791 & & 2,791 & & 2,791 & \\
\hline$R$-square & 0.223 & & 0.221 & & 0.264 & \\
\hline
\end{tabular}

Keterangan : 1) $* * * p<0.01, * * p<0.05, * p<0.1$. 2) Angka dalam kurung menunjukkan standar error. 3) Sampel 1 adalah pasangan bapak dan anak di mana bapak mempunyai informasi pendapatan yang lengkap di 3 titik waktu 
Sementara itu, dengan menggunakan 2SLS, model (3) menunjukkan bahwa pendidikan orang tua berpengaruh signifikan terhadap pendidikan anak dengan koefisien sebesar 0.322 , artinya kenaikan 1 tahun lama sekolah bapak akan meningkatkan lama pendidikan anak sebesar 0.322 tahun ketika hal lainnya dikontrol. Adanya korelasi yang positif antara pendidikan orang tua dengan pendidikan anak mengindikasikan bahwa orang tua yang berpendidikan tinggi akan mempunyai perhatian lebih kepada pendidikan anak. Angka ini lebih rendah dari penelitian Hertz et al (2007) yang menemukan bahwa korelasi capaian pendidikan antara orang tua dan anak di Indonesia masih cenderung tinggi yaitu sebesar 0.55. Sebagai tambahan, pendapatan bapak juga mempunyai pengaruh yang signifikan terhadap lama pendidikan anak. Kenaikan 10 persen pendapatan bapak akan meningkatkan lama sekolah anak sebesar 0.056 tahun ketika hal lain di kontrol. Hal ini menggambarkan mekanisme transmisi modal manusia melalui saluran investasi model manusia dari orang tua ke anak. Orang tua yang berpendidikan tinggi mempunyai kemampuan finansial yang lebih untuk berinvestasi kepada modal manusia anaknya. Selain itu, umur anak dan karakteristik tempat tinggal juga mempengaruhi lama pendidikan anak.

Model (2) menunjukkan hasil estimasi 2SLS yang merujuk pada persamaan (17). Model (2) menghasilkan angka IGE sebesar 0.151, artinya kenaikan 1 persen ratarata pendapatan bapak akan meningkatkan pendapatan anak sebesar 0.151 persen ketika hal lain dikontrol. Jika dibandingkan dengan IGE pada model (1), IGE yang dihasilkan pada model (2) lebih tinggi.

Hasil empiris di atas mendukung dugaan bahwa transfer modal manusia mempunyai pengaruh terhadap besaran IGE. IGE yang mengandung transfer langsung modal manusia yang diperoleh pada model (2) yaitu sebesar 0.151 lebih besar daripada IGE yang tidak memasukkan transfer langsung modal manusia pada model (1) yaitu sebesar 0.118. Hal ini diperkuat secara statistik bahwa kedua IGE memang berbeda. Hasil uji $t$ dua arah menunjukkan nilai $p$-value yaitu 0.0000 lebih kecil daripada $\alpha=1 \%$ yang artinya menolak hipotesis nol bahwa kedua rata-rata tidak berbeda secara statistik. Berdasarkan hal tersebut maka dapat dikatakan bahwa IGE model (2) yaitu 0.151 lebih besar daripada estimasi IGE model (1) yaitu 0.118 .

Dengan demikian, dapat dikatakan bahwa transfer langsung modal manusia antargenerasi, yang digambarkan oleh lama pendidikan bapak, meningkatkan korelasi atau kaitan antara pendapatan permanen bapak dengan pendapatan permanen anak. Transfer modal manusia memperkuat besaran IGE. Hasil empiris ini sejalan dengan penelitian Qin, Wang, \& Zhuang (2016) di China mengenai pengaruh transfer modal manusia antargenerasi terhadap mobilitas pendapatan antargenerasi yang menunjukkan bahwa transfer langsung modal manusia (melalui pendidikan dan kesehatan) meningkatkan estimasi IGE dari 0.429 menjadi 0.481 .
Dengan menggunakan sampel yang berbeda yaitu dengan menyertakan sebagian observasi bapak yang tidak mempunyai informasi pendapatan yang lengkap, tabel 4. menyajikan hasil estimasi IGE dengan langkah dan spesifikasi model yang sama dengan tabel 3. Dapat dilihat bahwa IGE yang dihasilkan dengan menggunakan sampel 2 lebih kecil jika dibandingkan dengan IGE yang dihasilkan dengan menggunakan sampel 1, baik untuk model (1) maupun model (2). Dapat dikatakan bahwa penggunaan sampel observasi yang berbeda menyebabkan perbedaan besaran IGE. IGE yang dihasilkan dengan menggunakan observasi pasangan bapak dan anak dan menyertakan bapak yang mempunyai informasi pendapatan yang tidak lengkap akan menghasilkan IGE yang lebih kecil. Hal ini menunjukkan bahwa penggunaan pendapatan di dua titik pengamatan belum bisa mengatasi kesalahan pengukuran. Kesalahan pengukuran karena penggunaan rata-rata di 2 titik pengamatan akan cenderung membuat IGE bias ke bawah. Hal ini sesuai dengan literatur sebelumnya (Mazumder, 2005; Solon, 1992). Solon (1992) menemukan bahwa estimasi IGE di US yang menggunakan rata-rata pendapatan di dua titik pengamatan menghasilkan IGE yang lebih kecil yaitu sekitar 0.3 daripada estimasi IGE yang menggunakan rata-rata pendapatan minimal 3 titik pengamatan yaitu sekitar 0.4 .

Pada tabel 4.estimasi IGE pada model (1), yang tidak mempertimbangkan transfer langsung modal manusia dan sudah mengontrol karakteristik anak menghasilkan angka sebesar 0.087 , artinya jika rata-rata pendapatan bapak meningkat sebesar 1 persen maka rata-rata pendapatan anak akan meningkat sebesar 0.087 persen. Sementara itu, dengan metode 2SLS, model (2) menghasilkan IGE sebesar 0.089 , artinya jika rata-rata pendapatan bapak meningkat sebesar 1 persen maka rata-rata pendapatan anak akan meningkat sebesar 0.089 persen.

Hasil estimasi IGE pada tabel 4. mempunyai arah dugaan yang sama dengan hasil estimasi IGE pada tabel 3. meskipun berbeda besaran. IGE yang diperoleh tanpa mempertimbangkan transfer langsung modal manusia mempunyai angka lebih kecil yaitu 0.087 daripada IGE yang sudah mempertimbangkan transfer langsung modal manusia yaitu sebesar 0.089 . Hal ini diperkuat secara statistik bahwa kedua IGE memang berbeda. Hasil uji $t$ dua arah menunjukkan nilai $p$-value yaitu 0.0139 lebih kecil daripada $\alpha=5 \%$ yang artinya menolak hipotesis nol bahwa kedua rata-rata tidak berbeda secara statistik. Berdasarkan hal tersebut maka dapat dikatakan bahwa IGE model (2) yaitu 0.089 lebih besar daripada estimasi IGE model (1) yaitu 0.087. Dapat dikatakan bahwa pengaruh transfer langsung modal manusia akan memperkuat besaran IGE.

Bukti empiris di Indonesia menunjukkan bahwa transfer langsung modal manusia memperkuat besaran IGE. IGE yang semakin besar dapat dijadikan indikasi 
Tabel 4. Hasil Estimasi IGE dengan Menggunakan Sampel Pasangan 2

\begin{tabular}{|c|c|c|c|c|c|c|}
\hline \multirow{3}{*}{ Variabel } & \multirow{2}{*}{\multicolumn{2}{|c|}{$\frac{\text { OLS }}{\substack{\text { Log natural pendapatan } \\
\text { tahunan anak }}}$}} & \multicolumn{4}{|c|}{ Persamaan Simultan } \\
\hline & & & \multirow{2}{*}{\multicolumn{2}{|c|}{$\begin{array}{c}\text { Log natural pendapatan tahunan } \\
\text { anak } \\
(2) \\
\end{array}$}} & \multicolumn{2}{|c|}{ Lama Pendidikan anak } \\
\hline & & & & & & \\
\hline $\begin{array}{l}\text { Log natural rata-rata pendapatan } \\
\text { tahunan bapak }\end{array}$ & $\begin{array}{c}0.087 \\
(0.019)\end{array}$ & $* * *$ & $\begin{array}{c}0.089 \\
(0.024)\end{array}$ & $* * *$ & $\begin{array}{c}0.483 \\
(0.047)\end{array}$ & $* * *$ \\
\hline Lama pendidikan anak & $\begin{array}{c}0.094 \\
(0.006)\end{array}$ & $* * *$ & $\begin{array}{c}0.092 \\
(0.016)\end{array}$ & $* * *$ & & \\
\hline Lama pendidikan bapak & & & & & $\begin{array}{c}0.356 \\
(0.013)\end{array}$ & $* * *$ \\
\hline Jenis Kelamin anak & $\begin{array}{l}-0.488 \\
(0.044)\end{array}$ & $* * *$ & $\begin{array}{l}-0.487 \\
(0.045)\end{array}$ & $* * *$ & $\begin{array}{c}0.644 \\
(0.102)\end{array}$ & $* * *$ \\
\hline Umur anak & $\begin{array}{c}0.294 \\
(0.023)\end{array}$ & $* * *$ & $\begin{array}{c}0.295 \\
(0.025)\end{array}$ & $* * *$ & $\begin{array}{c}0.020 \\
(0.008)\end{array}$ & $* * *$ \\
\hline Kuadrat umur anak & $\begin{array}{l}-0.004 \\
(0.000)\end{array}$ & $* * *$ & $\begin{array}{l}-0.004 \\
(0.000)\end{array}$ & $* * *$ & & \\
\hline Urban/rural & $\begin{array}{c}0.238 \\
(0.045)\end{array}$ & $* * *$ & $\begin{array}{c}0.240 \\
(0.048)\end{array}$ & $* * *$ & $\begin{array}{c}0.701 \\
(0.105)\end{array}$ & $* * *$ \\
\hline Status perkawinan & $\begin{array}{c}0.037 \\
(0.053)\end{array}$ & & $\begin{array}{c}0.038 \\
(0.054)\end{array}$ & & & \\
\hline Lama bekerja & $\begin{array}{c}0.006 \\
(0.000)\end{array}$ & $* * *$ & $\begin{array}{c}0.006 \\
(0.000)\end{array}$ & $* * *$ & & \\
\hline Sektor_industri & $\begin{array}{c}0.414 \\
(0.060)\end{array}$ & $* * *$ & $\begin{array}{c}0.414 \\
(0.060)\end{array}$ & $* * *$ & & \\
\hline Sektor_jasa & $\begin{array}{c}0.383 \\
(0.056)\end{array}$ & $* * *$ & $\begin{array}{c}0.383 \\
(0.056)\end{array}$ & $* * *$ & & \\
\hline Konstanta & $\begin{array}{l}7.423 \\
(0.440)\end{array}$ & $* * *$ & $\begin{array}{c}7.403 \\
(0.490)\end{array}$ & $* * *$ & $\begin{array}{l}-0.146 \\
(0.763)\end{array}$ & \\
\hline observasi & 3,940 & & 3,940 & & 3,940 & \\
\hline$R$-square & 0.231 & & 0.233 & & 0.290 & \\
\hline
\end{tabular}

Keterangan : 1) ***p<0.01, **p<0.05, *p<0.1. 2) Angka dalam kurung menunjukkan standar error. 3) Sampel 2 adalah pasangan bapak dan anak di mana bapak mempunyai informasi pendapatan minimal 2 titik waktu

bahwa kesenjangan yang terjadi pada generasi orang tua cenderung diwariskan atau dipertahankan ke generasi anak. Persistensi kesenjangan pendapatan antargenerasi dapat terjadi karena persistensi dari tingkat pendidikan antargenerasi. Hal tersebut mengimplikasikan bahwa ketika pengembangan modal manusia anak diserahkan sepenuhnya kepada keputusan rumah tangga, maka kesenjangan pendapatan akan terus dipertahankan dari generasi orang tua kepada generasi anak. Hal ini dikarenakan orang tua yang mempunyai modal manusia (pendidikan) yang tinggi dan memberikan investasi yang cukup tinggi untuk modal manusia anak-anaknya akan menghasilkan anak dengan modal manusia yang tinggi pula, sebaliknya orang tua yang mempunyai modal manusia tidak terlalu tinggi dan memberikan investasi yang kurang pada modal manusia anak-anaknya akan mempunyai anak dengan modal manusia yang tidak terlalu tinggi pula.

Sementara itu, penggunaan data untuk mengukur mobilitas pendapatan antargenerasi di Indonesia dapat memberi gambaran mengenai IGE di Indonesia yang relatif rendah. Hal ini dikarenakan data IFLS mengambil lebih banyak sampel responden di daerah maju, seperti di Pulau Jawa, yang mempunyai akses pendidikan yang lebih baik daripada daerah lain di Indonesia. Adanya akses pendidikan yang lebih baik kepada pendidikan dapat membantu generasi anak untuk mengembangkan modal manusianya terlepas dari latar belakang keluarganya meskipun ada kemungkinan bahwa transfer langsung modal manusia bekerja secara genetik. Dalam penelitiannya mengenai mobilitas pendapatan antargenerasi di US dan Kanada, Corak \& Heisz (1999) mengungkapkan bahwa Kanada mempunyai mobilitas pendidikan antargenerasi yang lebih tinggi daripada US karena Kanada mempunyai kebijakan publik yang lebih progresif daripada US yang membuat akses ke pendidikan lebih bagus. Ada kemungkinan bahwa IGE di Indonesia akan lebih tinggi jika data yang digunakan lebih representatif untuk Indonesia.

Sebagai informasi tambahan, akan lebih menarik untuk membedakan IGE antara anak laki-laki dan anak perempuan seperti yang sudah dilakukan oleh penelitian sebelumnya (Bevis \& Barrett, 2015; Qin, Wang, \& Zhuang, 2016). Bevis \& Barrett (2015) membandingkan IGE untuk anak laki-laki dan untuk perempuan di Rural Philipina dengan dugaan bahwa orang tua mempunyai ekspektasi dan preferensi yang berbeda tergantung pada jenis kelamin anak. Orang tua mungkin melihat tingkat 
Tabel 5. Perbedaan IGE Antara Anak Laki-laki dan Anak Perempuan dengan Menggunakan Sampel 1

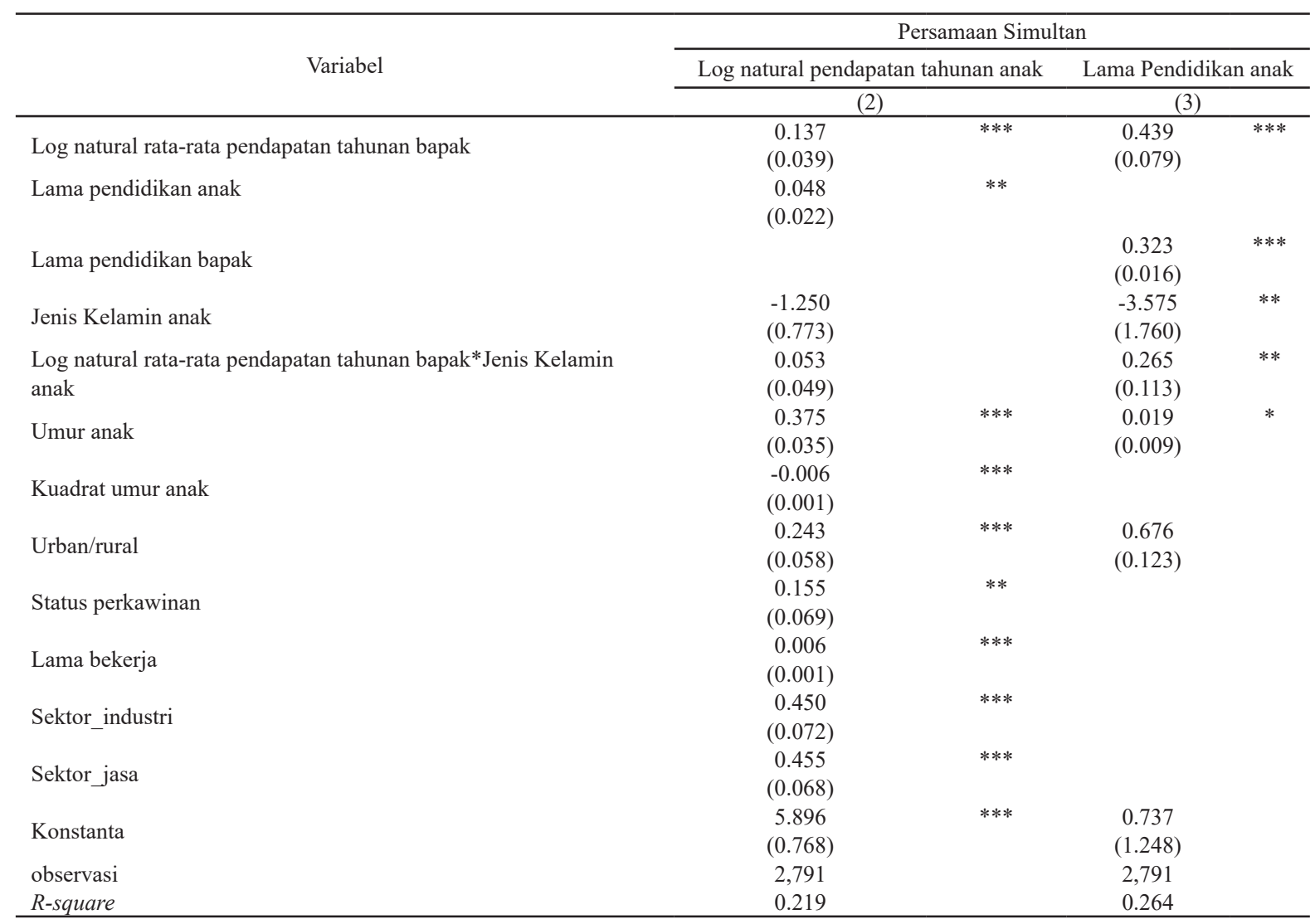

Keterangan : 1) $* * * \mathrm{p}<0.01, * * \mathrm{p}<0.05, * \mathrm{p}<0.1$. 2) Angka dalam kurung menunjukkan standar error. 3) Sampel 1 adalah pasangan bapak dan anak di mana bapak mempunyai informasi pendapatan yang lengkap di 3 titik waktu

pengembalian dari pendidikan berbeda antar jenis kelamin anak. Hasilnya adalah IGE anak perempuan lebih tinggi daripada anak laki-laki dan pendapatan orang tua mempengaruhi pendapatan anak perempuan secara kuat, sedangkan untuk anak laki-laki terdapat transmisi lain dari orang tua ke anak yaitu melalui modal fisik (lahan pertanian). Hal ini menunjukkan bahwa kebijakan untuk membatasi lahan pertanian orang tua hanya efektif untuk menurunkan IGE anak laki-laki sedangkan tidak berpengaruh dalam menurunkan IGE untuk anak perempuan. Sementara itu, Qin, Wang, \& Zhuang (2016) membedakan IGE anak laki-laki dan IGE anak perempuan di China dan menemukan bahwa IGE anak perempuan (sebesar 0.464) lebih tinggi daripada IGE anak laki-laki (sebesar 0.415). Hal ini mengindikasikan bahwa perempuan masih termasuk dalam kelompok yang tidak diuntungkan dalam perkembangan ekonomi karena mereka tidak bisa memutus persistensi pendapatan antargenerasi. dengan kata lain, pendapatan anak perempuan di masa yang akan datang masih sangat dipengaruhi oleh pendapatan orang tua jika dibandingkan dengan anak laki-laki.

Untuk mengetahui perbedaan antara IGE lakilaki dengan perempuan, maka ditambahkan variabel interaksi dari rata-rata pendapatan bapak dan jenis kelamin anak pada persamaan simultan. Hasil estimasi disajikan oleh tabel 4.5 dengan menggunakan sampel 1 .
Berdasarkan tabel 5. terlihat bahwa variabel interaksi antara pendapatan permanen orang tua dengan jenis kelamin anak persamaan model (2) tidak signifikan secara statistik. Dapat dikatakan bahwa IGE tidak berbeda untuk anak laki-laki dan anak perempuan.

\section{SIMPULAN}

Penelitian ini memberikan gambaran mengenai transfer langsung modal manusia antargenerasi dan pengaruhnya terhadap mobilitas pendapatan antar generasi di Indonesia. Transfer langsung modal manusia dari orang tua ke anak berperan dalam memperkuat IGE. Modal manusia orang tua ditularkan secara langsung terhadap modal manusia anak. Dalam hal ini pendidikan orang tua masih memiliki korelasi yang cukup kuat terhadap pendidikan anak. Dapat dikatakan bahwa persistensi dari tingkat pendidikan inilah yang nantinya menyebabkan persistensi dari pendapatan antargenerasi. Hal ini dapat menjadi indikasi bahwa jika pengembangan modal manusia anak diserahkan sepenuhnya oleh keputusan dalam rumah tangga, maka kesenjangan yang terjadi pada generasi orang tua cenderung dipertahankan atau diwariskan kepada generasi anak.

Sementara itu, penggunaan data untuk mengukur mobilitas pendapatan antargenerasi di Indonesia dapat memberi gambaran mengenai IGE di Indonesia yang 
relatif rendah. Hal ini dikarenakan data IFLS mengambil lebih banyak sampel responden di daerah maju, seperti di Pulau Jawa, yang mempunyai akses pendidikan yang lebih baik daripada daerah lain di Indonesia. Hal ini dapat dijadikan indikasi bahwa adanya akses pendidikan yang lebih baik kepada pendidikan dapat membantu generasi anak untuk mengembangkan modal manusianya terlepas dari latar belakang keluarganya meskipun ada kemungkinan bahwa transfer langsung modal manusia bekerja secara genetik.

\section{DAFTAR PUSTAKA}

Becker, G.S. (1993). Human capital: A theoretical and empirical analysis with special reference to education. University of Chicago Press.

Becker, G.S. \& Tomes, N. (1979). An equilibrium theory of the distribution of income and intergenerational mobility. Journal of Political Economy 87 (6), 1153-1189.

Becker, G.S., Kominers, S. D., Murphy, K.M., \& Spenkuch, J.L. (2015). A Theory of Intergenerational Mobility. mimeographed, University of Chicago.

Behrman, J, \& Taubman, P. (1990). The intergenerational correlation between children's adult earnings and their parent's income: Results from the michigan panel survey of income dynamics. Review of Income and Wealth, 36 (2), 115-127.

Barrett, C.B. \& Bevis, L.E. (2015). Decomposing Intergenerational Income Elasticity: The Genderdifferentiated Contribution of Capital Transmission in Rural Philippines. World Development Vol. 74, 233-252.

Barrett, C.B. \& Naschold, F. (2011). Do short-term observed income changes overstate structural economic mobility? Oxford Bulletin of Economics and Statistics, 73(5), 705-717.

Björklund, A. \& Jäntti, M. (1997). Intergenerational income mobility in Sweden compared to the United. American Economic Review, 1009-1018.

Björklund, A. \& Jäntti, M. (2009). Intergenerational income mobility and the role of family background. in The Oxford Handbook of Economic Inequality.

Björklund, A., Roine, J. \& Waldenström, D. (2012). Intergenerational top income mobility in Sweden: Capitalist dynasties in the land of equal opportunity? Journal of Public Economics, 96, 474-484.

Black, S.E, \& Devereux, P.J. (2010). Recent Developments in Intergenerational Mobility. NBER working paper.
Blanden, J. (2013). Cross-country rankings in intergenerational mobility: A comparison of approaches from economics and sociology. Journal of Economic Surveys, 27(1), 38-73.

Blanden, J., Haveman, R., Smeeding, T. \& Wilson, K. (2014). Intergenerational Mobility in The United States and Great Britain : A Comparative Study of Parent-Child Pathways. Review of Income and Wealth 60(3), 425-449.

Corak, M. (2013). Income inequality, equality of opportunity, and intergenerational mobility. The Journal of Economic Perspectives, 27(3), 79-102.

Corak, M, \& Heisz, A. (1999). The intergenerational earnings and income mobility of Canadian men: Evidence from longitudinal income tax data. Journal of Human Resources, 34(3), 504-533.

Gong, H., Leigh, A, \& Meng, X. (2012). Intergenerational Income Mobility in Urban China. Review of Income and Wealth, 58(3), 481-503.

Haider, S, \& Solon , G. (2006). Life-cycle variation in the association between current and lifetime earnings. American Economic Review 96(4), 1308-1320.

Herrington, C.M. (2015). Public education financing, earnings inequality, and intergenerational mobility. Review of Economic Dynamics, 18(4), 822-842.

Hertz, T. \& Jayasundera, T. (2007). School Construction and Intergenerational in Indonesia. Department of Economics, American University Working Paper Series No. 2007-18.

Hertz, T., Jayasundera, T., Piraino, P., Selcuk, S., Smith, N, \& Verashchagina, A. (2007). The Inheritance of Educational Inequality: International Comparisons and Fifty-Year Trends. The B.E. Journal of Economic Analysis \& Policy, Vol 7(2), Article 10.

Lindquist, M. \& Bohlmark, A.(2006). Life-cycle variations in the association between current and lifetime income: Replication and extension for Sweden. Journal of Labor Economics 24(4), 879-896.

Mazumder, B. (2005). Fortunate sons: New estimates of intergenerational mobility in the United States using social security earnings data. Review of Economics and Statistics, 87(2), 235-255.

Osterbacka, E. (2001). Family background and economic status in Finland. The Scandinavian Journal of Economics, 103(3), 467-484. 
Piraino, P. (2015). Intergenerational Earnings Mobility and Equality of Opportunity in South Africa. World Development Vol. 67, 396-405.

Qin, X., Wang, T, \& Zhuang, C.C. (2016). Intergenerational transfer of human capital and its impact on income mobility : Evidence from China. China Economic Review 38, 306-321.

Senoaji, G. (2011). Kondisi Sosial Ekonomi Masyarakat Sekitar Hutan Lindung Bukit Daun di Bengkulu. Sosiohumaniora, Vol. 13, No. 1, 1-17.

Solon, G. (1992). Intergenerational Income Mobility in the United States. The American Economic Review, Vol. 82, No. 3, 393-408.

Solon, G. (2002). Cross-country differences in intergenerational earnings mobility. The Journal of Economic Perspectives, 16(3), 59-66.
Tain, A., (2013). Faktor Dominan Penyebab Kemiskinan Rumah Tangga Nelayan Motor Tempel di Wilayah Tangkap Lebih Jawa Timur. Sosiohumaniora, Vol. 15, No. 1, 35-44.

Wang, M. \& Li, Z., Liu, L., (2014). Intergenerational income mobility and public education spending: Evidence from China. Children and Youth Services Review, 40, 89-97.

Yuan, W. (2015). The Sins of the Fathers: Intergenerational Income Mobility in China. The Review of Income and Wealth.

Zimmerman, D. (1992). Regression toward Mediocrity in Economic Stature. The American Economic Review, 82(3), 409-429. 